\title{
Factors Associated With Access to HIV Testing and Primary Care Among Migrants Living in Europe: Cross-Sectional Survey
}

Ibidun Fakoya ${ }^{1}$, BSc (Hons), MSc; Débora Álvarez-del Arco ${ }^{2,3}$, BSc, PhD; Andrew J Copas ${ }^{1}$, BA, MSc, PhD; Bryan Teixeira ${ }^{4}$, BA, PhD; Koen Block ${ }^{4}$, BSc; Anne-Francoise Gennotte ${ }^{5}$, MD; Alain Volny-Anne ${ }^{4}$, BA; Janneke P Bil ${ }^{6,7}$, BSc; Giota Touloumi ${ }^{8}$, MSc, PhD; Julia del Amo ${ }^{2,3}, \mathrm{MSc}, \mathrm{MD}, \mathrm{PhD}$; Fiona M Burns ${ }^{1,9}, \mathrm{MSc}, \mathrm{MBChB}, \mathrm{PhD}$

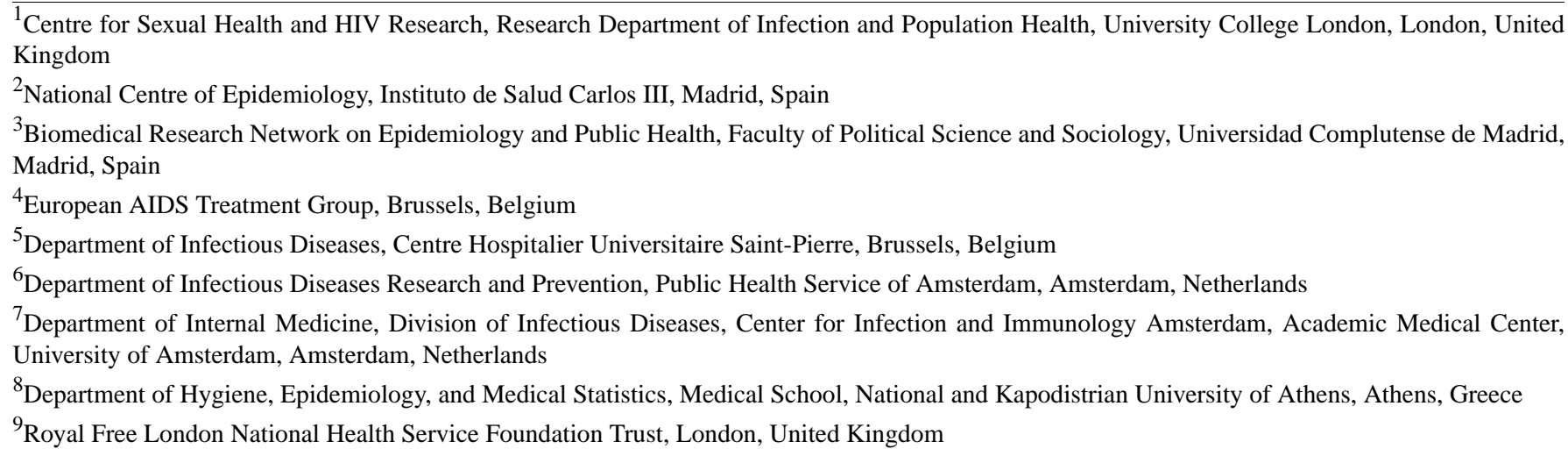

Corresponding Author:

Ibidun Fakoya, BSc (Hons), MSc

Centre for Sexual Health and HIV Research

Research Department of Infection and Population Health

University College London

3rd Floor, Mortimer Market Centre

Mortimer Market

London,

United Kingdom

Phone: 4402031082066

Fax: 4402031082066

Email: Ibidun.fakoya@ucl.ac.uk

\section{Abstract}

Background: There is a heavy and disproportionate burden of human immunodeficiency virus (HIV) infection among migrant communities living in Europe. Despite this, the published evidence related to HIV testing, prevention, and treatment needs for migrants is sparse.

Objective: The aim of this study was to identify the factors associated with access to primary care and HIV testing among migrant groups living in Europe.

Methods: A Web-based survey (available in 14 languages) was open to all people aged 18 years and older, living outside their country of birth in the World Health Organization (WHO) European area. Community organizations in 9 countries promoted the survey to migrant groups, focusing on those at a higher risk of HIV (sub-Saharan Africans, Latin Americans, gay or bisexual men, and people who inject drugs). Multivariable analysis examined factors associated with access to primary care and previous history of an HIV test.

Results: In total, 559 women, 395 heterosexual men, and 674 gay or bisexual men were included in the analysis, and $68.1 \%$ (359/527) of women, 59.5\% (220/371) of heterosexual men, and 89.6\% (596/664) of gay or bisexual men had tested for HIV. Low perceived risk was the reason given for not testing by $62.3 \%$ (43/69) of gay or bisexual men and 83.3\% (140/168) of women and heterosexual men who reported never having tested for HIV. Access to primary care was $>60 \%$ in all groups. Access to primary care was strongly positively associated with living in Northern Europe compared with Southern Europe (women: adjusted odds ratio, aOR 34.56 [95\% CI 11.58-101]; heterosexual men: aOR 6.93 [95\% CI 2.49-19.35], and gay or bisexual men: aOR 
2.53 [95\% CI 1.23-5.19]), whereas those with temporary residency permits were less likely to have access to primary care (women: aOR 0.41 [95\% CI 0.21-0.80] and heterosexual men: aOR 0.24 [95\% CI 0.10-0.54] only). Women who had experience of forced sex (aOR 3.53 [95\% CI 1.39-9.00]) or postmigration antenatal care (aOR 3.07 [95\% CI 1.55-6.07]) were more likely to have tested for HIV as were heterosexual men who had access to primary care (aOR 3.13 [95\% CI 1.58-6.13]) or reported "Good" health status (aOR 2.94 [95\% CI 1.41-5.88]).

Conclusions: Access to primary care is limited by structural determinants such as immigration and health care policy, which varies across Europe. For those migrants who can access primary care and other health services, missed opportunities for HIV testing remain a barrier to earlier testing and diagnosis for migrants in Europe. Clinicians should be aware of these potential structural barriers to HIV testing as well as low perception of HIV risk in migrant groups.

(JMIR Public Health Surveill 2017;3(4):e84) doi: 10.2196/publichealth.7741

\section{KEYWORDS}

HIV; migrants; HIV serodiagnosis; primary health care; health services accessibility

\section{Introduction}

Within Europe, migrant populations form a substantial proportion of the number of people living with human immunodeficiency virus (HIV). From 2007 to 2012, migrants represented two-fifths of HIV cases reported and had higher odds of late presentation compared with nonmigrants [1]. In 2014, the European Centre for Disease Control and Prevention reported that $31 \%$ of new diagnoses were among people living outside their country of birth [2]. Whereas trends show that new HIV diagnoses among migrants born outside Europe are decreasing, in the 9 years to 2014, the rates of new diagnosis among European-born migrants have increased by $48 \%$ [2]. Despite the disproportionate representation of migrants in the European HIV epidemic, the published evidence base related to the HIV testing, prevention, and treatment needs is sparse and mainly focuses on sub-Saharan migrants living in the European Union [3,4].

Migrants are at an increased risk of ill health in general and sexual ill health in particular $[5,6]$. Studies have highlighted that cultural, financial, and structural barriers may prevent migrants from accessing HIV health care services [4,7-11]. Yet these studies focus on migrants originating from 1 region [7,9-14] or residing in 1 country [8,10-15], and few studies focus on the role of access to primary care as a gateway to providing HIV testing and earlier diagnosis [16-18]. Additionally, recent literature reviews have found that the evidence base for understanding HIV risk behaviors among migrant men who have sex with men is similarly poor [19].

This paper presents findings from the Advancing Migrant Access to Health Services in Europe (aMASE) study. This collaborative European study aimed to provide the evidence to prevent HIV infection and improve diagnosis and prognosis of migrant populations living with HIV in Europe to support policy development at the European level. Our study objectives were to identify the structural, cultural, and financial barriers to HIV prevention, diagnosis, and treatment among migrants living in Europe. We present the findings of a community participatory cross-sectional survey that identifies the factors associated with access to health care and HIV testing among multiple migrant groups.

\section{Methods}

\section{Study Design}

Full details of the methods used in the aMASE study have been described elsewhere [20]. In summary, all people aged 18 years and older living outside their country of birth in the World Health Organization (WHO) European area, irrespective of their HIV status or current country of residence, were eligible to participate in the aMASE community survey. The survey, hosted by FluidSurveys version 5.0 (Fluidware, now SurveyMonkey), was available online between April 2014 and July 2015.

No sampling frame for migrants in Europe exists; therefore, a convenience sampling strategy was used. In calculating the sample size, the primary outcome measures were access to primary care and the proportion of participants previously tested for HIV-both assumed to have an overall outcome prevalence of $50 \%$. The target sample size was 1000 migrants, which allowed for estimates of the primary outcomes by gender within $5 \%$. The survey was actively promoted from June 2014 to May 2015 using social marketing and community participatory methods in Belgium, France, Germany, Greece, Italy, The Netherlands, Portugal, Spain, and the United Kingdom. These countries were selected because they complemented data available from a companion study, the aMASE clinic survey [20]. A Community Advisory Group (CAG) comprising representatives from local community-based organizations providing services to migrant communities was contracted to promote the survey as previously described [20]. The CAG was given promotional materials, and the survey was advertised on websites, social media, and dating sites (eg, Grindr and Gay Romeo). Four population groups with unmet HIV prevention needs [21] were targeted for recruitment: sub-Saharan Africans, Latin Americans, men who have sex with men, and people who inject drugs.

The survey instrument was available in 14 languages: Amharic, Arabic, Dutch, English, French, German, Greek, Italian, Polish, Portuguese, Russian, Turkish, Spanish, and Somali. All participants provided within-survey tick-box consent.

\section{Ethics}

Ethical approval was obtained from the London Bentham Research Ethics Committee (11/LO/1600). Additional approvals 
were obtained in countries that actively promoted the survey [20].

\section{Outcomes and Variables of Interest}

The main outcome measures were access to primary care and ever having tested for HIV. Access to primary care was defined as reported possession of a health card (Italy and Spain), access to a permanent medical doctor (Greece), or registration with a family doctor or general practitioner (GP) for all other countries. Respondents who reported living with diagnosed HIV were excluded from analysis identifying factors associated with ever having tested for HIV.

Data were analyzed separately for 3 gender-related groups as it was assumed that women, men who reported their sexual orientation as straight, and men who identified as gay or bisexual were all likely to be different with regard to HIV testing history, sexual behavior, and HIV prevention needs.

Geographical variables (region of birth, region of current country of residence) were created using geographic regions and subregions classifications by the United Nations Statistics Division [22].

\section{Statistical Analysis}

We undertook statistical analysis using Stata version 14.1 (StataCorp LLC). Individuals who reported their gender as other or who had not been-or did not intend to be-living in their current country of residence for 6 months or more were excluded from the analysis. Binary logistic regression was used to examine associations between demographic and behavior variables and the main outcome measures; we present crude odds ratios (OR) and adjusted OR (aOR) for each gender. Behavior and demographic factors that showed significant associations (alpha=.05) in a univariate analysis were included in a backwards stepwise model selection process conducted separately for each gender. We specified a priori that age, region of birth, sexual orientation, immigration status, and age at migration or diagnosis would be factors of interest in a multivariable analysis [20]. After models were selected, we examined whether associations between the primary outcomes and the included factors differed significantly by region of current residence or by region of birth by testing interaction terms.

\section{Results}

The exact number of individuals invited to complete the survey or who saw advertising online or via a dating app is unknown; therefore, an overall participation rate is unavailable. It is known that 3420 individuals completed the within-survey consent form (102 or $2.98 \%$ declined to take part at that stage). Of the 3321 people who agreed to participate, 1727 went on to complete the survey, of whom 1637 (49.29\% of those who consented) were included in the analysis (90 tourists were excluded from further analysis). Attrition rate analysis showed that $85.93 \%$ (2217/2580) of those who dropped out did so by question 7 (data not shown).

The 1637 respondents, of which $34.15 \%$ (559/1637) were women, reported 140 different countries of birth and 31 different countries as their current residence ( 9 transgender individuals were excluded from further analysis; see Multimedia Appendix 1 for full list of countries). The survey's targeted populations were well represented, with $62.96 \%$ (673/1069) of men identifying as gay or bisexual (209/673 born in Latin America and the Caribbean), 3.96\% (64/1618) of participants reporting a history of injecting drugs, and around half of women (272/559) and heterosexual men (214/396) born in Africa or Latin America and the Caribbean (Table 1).

Participants differed across gender for almost all sociodemographic characteristics, with the notable exception of age at migration (Table 1), and the average age of gay or bisexual men was lower than in the other 2 groups. Just over a fifth $(148 / 673,22.0 \%)$ of gay or bisexual men reported living with diagnosed HIV compared with $8.8 \%$ (49/559) of women and $6.6 \%(26 / 396)$ of heterosexual men $(P<.001)$ (Table 1 ; see also Multimedia Appendices 1-3 for full demographic details). 
Table 1. Sociodemographic characteristics of respondents, by gender (men separated by self-reported sexual orientation).

\begin{tabular}{|c|c|c|c|c|}
\hline Sociodemographics & Women & Heterosexual men & Gay or bisexual men & $P$ value $^{\mathrm{a}}$ \\
\hline Current country of residence (by European region), $\mathbf{n}(\%)^{\mathrm{b}, \mathrm{c}}$ & & & & $<.001$ \\
\hline Northern Europe & $124(22.1)$ & $46(11.6)$ & $123(18.3)$ & \\
\hline Southern Europe & $279(49.9)$ & $261(65.9)$ & $139(20.7)$ & \\
\hline Rest of Europe & $156(27.9)$ & $89(22.5)$ & $411(61.1)$ & \\
\hline Age, years, median $(\mathrm{IQR})^{\mathrm{b}, \mathrm{d}}$ & $35(28-43)$ & $36(28-43)$ & $33(28-43)$ & $<.001$ \\
\hline In current country, years, median (IQR) $)^{\mathrm{b}, \mathrm{d}}$ & $8(3-13)$ & $8(3-15)$ & $5(2-12)$ & $<.001$ \\
\hline Age at migration, years, mean $(\mathrm{SD})^{\mathrm{b}, \mathrm{e}}$ & $26.8(10.3)$ & $27.2(10.1)$ & $26.8(9.3)$ & .78 \\
\hline Region of birth, $\mathbf{n}(\%)^{\text {b,f }}$ & & & & $<.001$ \\
\hline Africa & $155(27.7)$ & $167(42.2)$ & $36(5.4)$ & \\
\hline Latin America and the Caribbean & $117(20.9)$ & 47 (11.9) & $209(31.1)$ & \\
\hline Rest of the world & $24(4.3)$ & $4(1.0)$ & $38(5.7)$ & \\
\hline Asia & $43(7.7)$ & $71(17.9)$ & $57(8.5)$ & \\
\hline Europe & $220(39.4)$ & $107(27.2)$ & $333(49.5)$ & \\
\hline Ethnicity $(n=1618), n(\%)$ & & & & $<.001$ \\
\hline Arab or Magrhebian & $13(2.4)$ & $30(7.7)$ & $9(1.3)$ & \\
\hline Asian & $28(5.1)$ & $42(10.7)$ & $49(7.3)$ & \\
\hline Black African or Caribbean & $125(22.6)$ & $125(31.9)$ & $17(2.5)$ & \\
\hline Latin American or Hispanic & 64 (11.6) & $31(7.9)$ & $124(18.5)$ & \\
\hline Mixed ethnicity & $40(7.2)$ & $21(5.4)$ & $88(13.1)$ & \\
\hline Other & $44(7.9)$ & $55(14.0)$ & $39(5.8)$ & \\
\hline White European & $201(36.3)$ & $83(21.2)$ & $302(44.9)$ & \\
\hline White other & $39(7.0)$ & $5(1.3)$ & $44(6.6)$ & \\
\hline Education: upper secondary or more, $\mathrm{n}(\%)^{\mathrm{b}}$ & $398(71.2)$ & $248(62.6)$ & $600(89.2)$ & $<.001$ \\
\hline Employment: working full- or part-time, $\mathrm{n}(\%)^{\mathrm{b}}$ & $297(53.1)$ & $177(44.7)$ & $501(74.4)$ & $<.001$ \\
\hline Relationship status, $\mathbf{n}(\%)^{\mathrm{b}}$ & & & & $<.001$ \\
\hline Married or cohabitating & $283(50.6)$ & $165(41.7)$ & $205(30.5)$ & \\
\hline Single & $206(36.8)$ & $182(46.0)$ & $397(59.0)$ & \\
\hline Living apart relationship or marriage & $70(12.5)$ & $49(12.3)$ & $71(10.6)$ & \\
\hline Religion of those who attend services $(n=627), n(\%)$ & & & & $<.001$ \\
\hline Christian (all denominations) & $196(83.4)$ & $119(59.5)$ & $167(87.0)$ & \\
\hline Muslim or Islam & $23(9.8)$ & $66(33.0)$ & $9(4.7)$ & \\
\hline Other & $16(6.8)$ & $15(7.5)$ & $16(8.3)$ & \\
\hline \multicolumn{3}{|l|}{ Monthly income compared with national minimum wage $(\mathrm{n}=1575), \mathrm{n}(\%)$} & & $<.001$ \\
\hline More or a lot more & $169(32.1)$ & $113(29.4)$ & $372(56.0)$ & \\
\hline About the same & $65(12.3)$ & $40(10.4)$ & $88(13.3)$ & \\
\hline Less than minimum wage & $122(23.2)$ & $89(23.2)$ & $120(18.1)$ & \\
\hline No earnings & $171(32.5)$ & $142(37.0)$ & $84(12.7)$ & \\
\hline Not known & $169(32.1)$ & $113(29.4)$ & $372(56.0)$ & \\
\hline Moderate or severe household hunger in the past 4 weeks ( $\mathrm{n}=1520), \mathrm{n}(\%)$ & $130(25.8)$ & $121(34.5)$ & $89(13.4)$ & $<.001$ \\
\hline Immigration status, $\mathrm{n}(\%)(\mathrm{n}=1625)$ & & & & $<.001$ \\
\hline
\end{tabular}




\begin{tabular}{|c|c|c|c|c|}
\hline Sociodemographics & Women & Heterosexual men & Gay or bisexual men & $P$ value $^{\mathrm{a}}$ \\
\hline Permanent residency & $343(61.6)$ & $183(46.3)$ & $482(71.6)$ & \\
\hline Temporary residency & $86(15.4)$ & $84(21.3)$ & $157(23.3)$ & \\
\hline Asylum seeker or refugee status & $35(6.3)$ & $63(16.0)$ & $9(1.3)$ & \\
\hline Undocumented $^{\mathrm{f}}$ & $78(14.0)$ & $55(13.9)$ & $23(3.4)$ & \\
\hline Unknown & $15(2.7)$ & $10(2.5)$ & $2(0.3)$ & \\
\hline Living with diagnosed HIV, $\mathrm{n}(\%)^{\mathrm{b}, \mathrm{g}}$ & $49(8.8)$ & $26(6.6)$ & $148(22.0)$ & $<.001$ \\
\hline Previously injected drugs $(\mathrm{n}=1618), \mathrm{n}(\%)$ & $19(3.4)$ & $20(5.1)$ & $25(3.7)$ & .38 \\
\hline
\end{tabular}

${ }^{\mathrm{a}}$ Chi-square comparing gender-related groups.

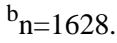

${ }^{c}$ Respondents living in Cyprus (classified as Western Asia by the United Nations but included in the World Health Organization European area) were classified as living in Southern Europe.

${ }^{\mathrm{d}} \mathrm{IQR}$ : interquartile range.

${ }^{\mathrm{e}} \mathrm{SD}$ : standard deviation.

f Those who checked "None of the above" in the multichoice list of all possible immigration statuses.

${ }^{\mathrm{g}}$ Self-reported HIV status.

Overall, $60.8 \%$ (236/388) of heterosexual men, 73.3\% (399/544) of women, and $72.6 \%$ (484/667) of gay or bisexual men reported access to a primary care physician (Table 2). The majority of participants had attended health care services in their current country of residence in the past 12 months, although $13.6 \%$ (76/559) of women, $8.8 \%$ (35/396) of heterosexual men, and $19.5 \%(131 / 673)$ of gay or bisexual men had returned to their country of birth and attended health care services in the previous 12 months. In each gender-related group, over $97 \%$ of the people who reported living with diagnosed HIV described visiting their HIV doctor in the last 12 months. More than a third $(9 / 25,36 \%)$ of heterosexual men, $25 \%$ (12/48) of women, and $4.9 \%$ (7/143) of gay or bisexual men reported missing appointments at their HIV clinic because of travel costs. Paying prescription costs was a difficulty for $53 \%(9 / 17)$ of heterosexual men, $41 \%$ $(15 / 37)$ of women, and $19.1 \%$ (20/105) of gay or bisexual men living with diagnosed HIV. 
Table 2. Access to health care services and human immunodeficiency virus testing among participants by gender (men separated by self-reported sexual orientation).

\begin{tabular}{|c|c|c|c|}
\hline Services and testing variables & $\begin{array}{l}\text { Women } \\
\mathrm{n}(\%)\end{array}$ & $\begin{array}{l}\text { Heterosexual men } \\
\mathrm{n}(\%)\end{array}$ & $\begin{array}{l}\text { Gay or bisexual men } \\
\mathrm{n}(\%)\end{array}$ \\
\hline Living with 1 or more chronic illnesses, not $\mathrm{HIV}^{\mathrm{a}}(\mathrm{n}=1628)$ & $183(32.7)$ & $126(31.8)$ & $243(36.1)$ \\
\hline Has access to primary care physician $(\mathrm{n}=1599)$ & $399(73.3)$ & $236(60.8)$ & $484(72.6)$ \\
\hline Visited $\mathrm{COB}^{\mathrm{b}}$ for health care in the last 12 months $(\mathrm{n}=1628)$ & $76(13.6)$ & $35(8.8)$ & $131(19.5)$. \\
\hline Doctor or nurse visited in $\mathrm{CCOR}^{\mathrm{c}}$ in the last 12 months $(\mathrm{n}=1625)$ & $484(86.6)$ & $311(78.9)$ & $539(80.2)$ \\
\hline \multicolumn{4}{|l|}{ Health care service attended in CCOR ever $(n=1628)$} \\
\hline Any health service & $519(92.8)$ & $361(91.2)$ & $587(87.2)$ \\
\hline $\mathrm{GP}^{\mathrm{d}}$ or family doctor & $374(66.9)$ & $197(49.7)$ & $433(64.3)$ \\
\hline $\mathrm{STI}^{\mathrm{e}}$ clinic & $75(13.4)$ & $48(12.1)$ & $346(51.4)$ \\
\hline Emergency & $251(44.9)$ & $149(37.6)$ & $261(38.8)$ \\
\hline Outpatient & $187(33.5)$ & $103(26.0)$ & $193(28.7)$ \\
\hline Inpatient & $148(26.5)$ & $99(25.0)$ & $153(22.7)$ \\
\hline Outreach & $24(4.3)$ & $41(10.4)$ & $9(1.3)$ \\
\hline Antenatal & $138(24.7)$ & $4(1.0)$ & - \\
\hline \multicolumn{4}{|l|}{ HIV testing mentioned during attendance $(n=1467)$} \\
\hline Any health service & $196(37.8)$ & $129(35.7)$ & $374(63.7)$ \\
\hline Inpatient $(\mathrm{n}=400)$ & $31(20.9)$ & $26(26.3)$ & $28(18.3)$ \\
\hline Emergency $(\mathrm{n}=661)$ & $9(3.6)$ & $11(7.4)$ & $23(8.8)$ \\
\hline Antenatal $(\mathrm{n}=142)$ & $67(48.6)$ & $0(0)$ & - \\
\hline STI clinic $(\mathrm{n}=469)$ & $40(53.3)$ & $25(52.1)$ & $274(79.2)$ \\
\hline Outpatient $(\mathrm{n}=483)$ & $13(7.0)$ & $15(14.6)$ & $30(15.5)$ \\
\hline Outreach $(\mathrm{n}=74)$ & $21(87.5)$ & $32(78.0)$ & $7(77.8)$ \\
\hline GP or family doctor $(n=1004)$ & $53(14.2)$ & $36(18.3)$ & $159(36.7)$ \\
\hline Previously tested for HIV $(n=1562)$ & $359(68.1)$ & $220(59.6)$ & $596(89.6)$ \\
\hline \multicolumn{4}{|l|}{ Place diagnosed or of last test $(n=1086)$} \\
\hline Antenatal service & $51(14.7)$ & $2(0.9)$ & $1(0.2)$ \\
\hline Hospital service (emergency, inpatient, or outpatient) & $68(19.6)$ & $57(26.4)$ & $56(10.7)$ \\
\hline GP or family doctor & $46(13.3)$ & $21(9.7)$ & $108(20.7)$ \\
\hline Sexual health clinic or HIV testing clinic & $58(16.7)$ & $36(16.7)$ & $250(47.8)$ \\
\hline Community or outreach setting & $41(11.8)$ & $50(23.1)$ & $43(8.2)$ \\
\hline Private clinic & $36(10.4)$ & $11(5.1)$ & $42(8.0)$ \\
\hline Other & $47(13.5)$ & $39(18.1)$ & $23(4.4)$ \\
\hline \multicolumn{4}{|l|}{ Reasons for never testing $(n=387)$} \\
\hline Perceived low risk & $140(83.3)$ & $125(83.3)$ & $43(62.3)$ \\
\hline Fear of positive result and consequences & $8(4.8)$ & $10(6.7)$ & $17(24.6)$ \\
\hline Structural barriers to accessing health care & $15(8.9)$ & $11(7.3)$ & $17(24.6)$ \\
\hline Fear of test procedure & $3(1.8)$ & $6(4.0)$ & $3(4.3)$ \\
\hline Other & $20(11.9)$ & $10(6.7)$ & $6(8.7)$ \\
\hline \multicolumn{4}{|l|}{ Reasons for last test $(n=1175)$} \\
\hline Perceived risk & $57(15.9)$ & $46(20.8)$ & $227(38.2)$ \\
\hline
\end{tabular}




\begin{tabular}{|c|c|c|c|}
\hline Services and testing variables & $\begin{array}{l}\text { Women } \\
\mathrm{n}(\%)\end{array}$ & $\begin{array}{l}\text { Heterosexual men } \\
\mathrm{n}(\%)\end{array}$ & $\begin{array}{l}\text { Gay or bisexual men } \\
\mathrm{n}(\%)\end{array}$ \\
\hline Feeling unwell or health problems & $38(10.6)$ & $30(13.6)$ & $58(9.7)$ \\
\hline Routine health checkup & $148(41.2)$ & $96(43.4)$ & $337(56.6)$ \\
\hline Pregnancy, blood donation, or other hospital appointment & $80(22.3)$ & $10(4.5)$ & $8(1.3)$ \\
\hline Job application, visa, or insurance & $23(6.4)$ & $20(9.0)$ & $17(2.9)$ \\
\hline Other & $47(13.1)$ & $44(19.9)$ & $36(6.1)$ \\
\hline \multicolumn{4}{|l|}{ People living with HIV only (n=223) } \\
\hline Previous negative HIV test $(\mathrm{n}=208)$ & $20(45.5)$ & $8(38.1)$ & $111(77.6)$ \\
\hline Visited an HIV doctor in the past 12 months ( $\mathrm{n}=221$ ) & $48(98.0)$ & $25(100)$ & $143(97.3)$ \\
\hline Missed appointments because of travel costs $(\mathrm{n}=216)$ & $12(25.0)$ & $9(36.0)$ & $7(4.9)$ \\
\hline Delayed or forwent medication because of prescription costs $(n=159)$ & $15(40.5)$ & $9(52.9)$ & $20(19.1)$ \\
\hline
\end{tabular}

${ }^{\mathrm{a}} \mathrm{HIV}$ : human immunodeficiency virus.

${ }^{\mathrm{b}} \mathrm{COB}$ : country of birth.

${ }^{\mathrm{c}} \mathrm{CCOR}$ : current country of residence.

${ }^{\mathrm{d}} \mathrm{GP}$ : general practitioner.

${ }^{\text {e}}$ STI: sexually transmitted infection.

The most frequently attended health service postmigration was general practice. Access to primary care (regardless of actual attendance) varied according to current region of residence (Table 3). Among women, this ranged from nearly ubiquitous access in Northern Europe $(120 / 124,96.8 \%)$ to less widespread access in Southern Europe at 56.4\% (149/264, Table 3). This pattern was similar among heterosexual men; however, for gay or bisexual men, the lowest access to primary care was observed in the Western and rest of Europe regions (284/411, 69.1\%). Multivariable analysis showed that differences in access to primary care among the regions in Europe remained significant for all 3 gender-related groups (Table 3). For women, additional

factors that influenced access to care were world region of birth and immigration status. Among heterosexual men, region of birth and immigration status remain significant after adjusting for other factors, including religious practice and number of children cared for in the home (Table 3). Gay or bisexual men living with HIV were more than twice as likely to have access to primary care (aOR $2.74,95 \%$ CI $1.53-4.86 ; P=.001$ ), but individuals who had been resident in their current country for less than 1 year were less likely to be in receipt of primary care than those who had been in the country for 2 to 5 years (aOR $0.32,95 \%$ CI 0.19-0.53). 
Table 3. Factors associated with access to primary care, by gender (men separated by self-reported sexual orientation).

\begin{tabular}{|c|c|c|c|c|c|}
\hline Factors $^{\mathrm{a}}$ & $\mathrm{n}(\%)$ & $\mathrm{OR}^{\mathrm{b}}$ & $\mathrm{aOR}{ }^{\mathrm{c}}$ & $95 \% \mathrm{CI}$ & $P$ value \\
\hline \multicolumn{6}{|l|}{ Women $(n=541)$} \\
\hline Current region of residence & & & & & $<.001$ \\
\hline Northern Europe & $120(96.8)$ & 23.15 & 34.56 & $11.58-101$ & \\
\hline Southern Europe & $149(56.4)$ & 1.00 & 1.00 & - & \\
\hline Western and rest of Europe & $130(85.0)$ & 4.01 & 5.30 & $3.00-9.39$ & \\
\hline Age, years & & & & & .79 \\
\hline $18-24$ & $29(67.4)$ & 0.88 & 1.26 & $0.55-2.86$ & \\
\hline $25-34$ & $152(69.4)$ & 1.00 & 1.00 & - & \\
\hline $35-44$ & $117(77.0)$ & 1.52 & 1.09 & $0.61-1.92$ & \\
\hline $45-54$ & $65(75.6)$ & 1.41 & 0.88 & $0.43-1.78$ & \\
\hline $55+$ & $36(87.8)$ & 3.27 & 1.78 & $0.59-5.32$ & \\
\hline World region of birth & & & & & $<.001$ \\
\hline Africa & $106(72.1)$ & 1.02 & 1.70 & $0.91-3.17$ & \\
\hline Latin America and the Caribbean & $94(80.3)$ & 1.62 & 5.71 & $2.85-11.43$ & \\
\hline Rest of the world & $45(69.2)$ & 0.89 & 0.95 & $0.42-2.15$ & \\
\hline Europe & $154(71.6)$ & 1.00 & 1.00 & - & \\
\hline Years resident in $\mathrm{CCOR}^{\mathrm{d}}$ & & & & & .18 \\
\hline 1 or less & $38(66.6)$ & 0.49 & 0.65 & $0.29-1.46$ & \\
\hline $2-5$ & $91(64.1)$ & 0.45 & 0.52 & $0.28-0.98$ & \\
\hline $6-9$ & $96(78.0)$ & 0.89 & 0.97 & $0.51-1.82$ & \\
\hline 10 or more & $174(79.5)$ & 1.00 & 1.00 & - & \\
\hline Immigration status & & & & & $<.001$ \\
\hline Permanent residency & $274(80.8)$ & 1.00 & 1.00 & - & \\
\hline Temporary residency & $51(60.7)$ & 0.37 & 0.41 & $0.21-0.80$ & \\
\hline Refugee status, unknown, or undocumented & $74(62.7)$ & 0.39 & 0.64 & $0.33-1.23$ & \\
\hline \multicolumn{6}{|l|}{ Heterosexual men $(n=301)$} \\
\hline Current region of residence & & & & & $<.001$ \\
\hline Northern Europe & $36(83.7)$ & 5.19 & 6.93 & $2.49-19.35$ & \\
\hline Southern Europe & $92(48.7)$ & 1.00 & 1.00 & - & \\
\hline Western and rest of Europe & $53(76.8)$ & 2.67 & 2.74 & $1.28-5.86$ & \\
\hline Age, years & & & & & .16 \\
\hline $18-24$ & $14(48.3)$ & 1.18 & 1.24 & $0.46-3.32$ & \\
\hline $25-34$ & $48(49.0)$ & 1.00 & 1.00 & - & \\
\hline $35-44$ & $49(58.3)$ & 1.76 & 1.10 & $0.51-2.34$ & \\
\hline $45-54$ & $42(73.7)$ & 2.71 & 1.89 & $0.76-4.70$ & \\
\hline $55+$ & $28(84.8)$ & 3.72 & 3.94 & $1.14-13.57$ & \\
\hline World region of birth & & & & & $<.001$ \\
\hline Africa & $71(61.7)$ & 0.96 & 2.14 & $0.92-4.95$ & \\
\hline Latin America and the Caribbean & $33(89.2)$ & 3.29 & 21.52 & $5.63-82.17$ & \\
\hline Rest of the world & $24(38.1)$ & 0.35 & 1.43 & $0.54-3.89$ & \\
\hline Europe & $53(61.6)$ & 1.00 & 1.00 & - & \\
\hline
\end{tabular}




\begin{tabular}{|c|c|c|c|c|c|}
\hline Factors $^{\mathrm{a}}$ & $\mathrm{n}(\%)$ & $\mathrm{OR}^{\mathrm{b}}$ & $\mathrm{aOR}^{\mathrm{c}}$ & $95 \% \mathrm{CI}$ & $P$ value \\
\hline Years resident in CCOR & & & & & .55 \\
\hline 1 or less & $14(48.3)$ & 0.37 & 1.20 & $0.40-3.59$ & \\
\hline $2-5$ & $40(46.5)$ & 0.31 & 0.65 & $0.30-1.41$ & \\
\hline $6-9$ & $31(62.0)$ & 0.71 & 0.93 & $0.40-2.16$ & \\
\hline 10 or more & $96(70.6)$ & 1.00 & 1.00 & - & \\
\hline Immigration status & & & & & .003 \\
\hline Permanent residency & $117(77.0)$ & 1.00 & 1.00 & - & \\
\hline Temporary residency & $28(45.2)$ & 0.26 & 0.24 & $0.10-0.54$ & \\
\hline Refugee status, unknown, or undocumented & $36(41.4)$ & 0.29 & 0.42 & $0.18-0.97$ & \\
\hline Religious practice & & & & & .14 \\
\hline Christian & $84(73.7)$ & 1.00 & 1.00 & - & \\
\hline Other & $33(44.6)$ & 0.33 & 0.66 & $0.29-1.46$ & \\
\hline Does not attend religious services & $64(56.6)$ & 0.50 & 0.51 & $0.25-1.05$ & \\
\hline One or more child cared for in the home & & & & & .13 \\
\hline No & $97(52.4)$ & 1.00 & 1.00 & - & \\
\hline Yes & $84(72.4)$ & 2.18 & 1.66 & $0.87-3.19$ & \\
\hline \multicolumn{6}{|l|}{ Gay or bisexual men $(n=667)$} \\
\hline Current region of residence & & & & & .03 \\
\hline Northern Europe & $98(79.7)$ & 1.19 & 2.53 & $1.23-5.19$ & \\
\hline Southern Europe & $102(76.7)$ & 1.00 & 1.00 & - & \\
\hline Western and rest of Europe & $284(69.1)$ & 0.68 & 1.28 & $0.74-2.20$ & \\
\hline Age, years & & & & & .38 \\
\hline $18-24$ & $50(53.8)$ & 0.54 & 0.74 & $0.43-1.26$ & \\
\hline $25-34$ & $186(68.1)$ & 1.00 & 1.00 & - & \\
\hline $35-44$ & $141(78.3)$ & 1.69 & 0.91 & $0.55-1.51$ & \\
\hline $45-54$ & $79(88.8)$ & 3.70 & 1.47 & $0.66-3.28$ & \\
\hline $55+$ & $28(87.5)$ & 3.27 & 2.12 & $0.60-7.49$ & \\
\hline World region of birth & & & & & .66 \\
\hline Africa & $28(82.4)$ & 1.75 & 1.83 & $0.63-5.28$ & \\
\hline Latin America and the Caribbean & $152(73.1)$ & 1.02 & 1.16 & $0.71-1.89$ & \\
\hline Rest of the world & $62(67.4)$ & 0.78 & 0.97 & $0.51-1.83$ & \\
\hline Europe & $242(72.7)$ & 1.00 & 1.00 & - & \\
\hline Years resident in CCOR & & & & & $<.001$ \\
\hline 1 or less & $40(38.5)$ & 0.09 & 0.10 & $0.05-0.19$ & \\
\hline $2-5$ & $152(65.5)$ & 0.26 & 0.32 & $0.18-0.56$ & \\
\hline $6-9$ & $102(88.7)$ & 1.07 & 1.19 & $0.57-2.48$ & \\
\hline 10 or more & $190(88.0)$ & 1.00 & 1.00 & - & \\
\hline Immigration status & & & & & .40 \\
\hline Permanent residency & $370(76.9)$ & 1.00 & 1.00 & - & \\
\hline Temporary residency & $97(62.2)$ & 0.49 & 0.86 & $0.51-1.45$ & \\
\hline Refugee status, unknown, or undocumented & $17(56.7)$ & 0.39 & 0.54 & $0.22-1.32$ & \\
\hline Living with diagnosed HIV ${ }^{\mathrm{e}}$ & & & & & .001 \\
\hline
\end{tabular}




\begin{tabular}{|c|c|c|c|c|c|}
\hline Factors ${ }^{\mathrm{a}}$ & $\mathrm{n}(\%)$ & $\mathrm{OR}^{\mathrm{b}}$ & $\mathrm{aOR}^{\mathrm{c}}$ & $95 \% \mathrm{CI}$ & $P$ value \\
\hline No & $355(68.3)$ & 1.00 & 1.00 & - & \\
\hline Yes & $129(87.8)$ & 3.33 & 2.72 & $1.53-4.86$ & \\
\hline
\end{tabular}

\footnotetext{
${ }^{\mathrm{a}}$ After the final model selection, each gender-related group adjusted for the factors listed under the corresponding heading in the table.

${ }^{\mathrm{b}} \mathrm{OR}$ : odds ratio.

${ }^{\mathrm{c}} \mathrm{aOR}$ : adjusted odds ratio.

${ }^{\mathrm{d}} \mathrm{CCOR}$ : current country of residence.

${ }^{\mathrm{e}} \mathrm{HIV}$ : human immunodeficiency virus.
}

More than two-thirds $(359 / 527,68.1 \%)$ of women, $59.5 \%$ (220/371) of men, and $89.6 \%$ (596/664) of gay or bisexual men had previously tested for HIV (Table 2). Respondents were asked about the place of their last test (or where they were diagnosed in the case of those living with HIV); whereas a fifth $(108 / 523)$ of gay or bisexual men had tested at the GP, only $13.3 \%(46 / 347)$ of women and $9.7 \%(21 / 216)$ of heterosexual men had done so. Just over half of women and heterosexual men $(40 / 75,53.3 \%$, and $25 / 48,52.1 \%$, respectively) and $79.2 \%$ (274/346) of gay men recalled being offered an HIV test in sexually transmitted infection (STI) clinics; $47.8 \%$ (250/523) of gay or bisexual men and $16.7 \%$ (58/347) of women and heterosexual men $(36 / 216)$ cited an STI clinic as the place of their last test. Less than half $(67 / 138,48.6 \%)$ of the women who had attended antenatal care recalled being offered a test, with $14.7 \%(51 / 347)$ of women reporting an antenatal service as the place of their last test. Among those who had attended a GP, over a third $(159 / 433,36.7 \%)$ of gay or bisexual men, $14.2 \%$ $(53 / 374)$ of women, and $18.3 \%(36 / 197)$ of heterosexual men recalled being offered an HIV test. Routine and quasi-routine health checks (such as pregnancy or other hospital appointments) were the impetus for testing for $63.5 \%$ (228/359) of women. Among all men, routine health checks and a perceived risk of HIV were the main reasons for testing.

Respondents who had never tested were asked to select their reasons for not having done so. Among women and heterosexual men, most (140/168, 83.3\%, and $125 / 150,83.3 \%$, respectively) who had not tested reported that they were at no or low risk, and a few $(8 / 168,4.8 \%$, and $10 / 150,6.7 \%$, respectively) reported fear of a positive test result. Although low risk of infection was a reason for not testing for $62.3 \%$ (43/69) of gay or bisexual men, around a quarter $(17 / 16,24.6 \%)$ also reported fears of a positive test result or structural barriers to accessing health care (Table 2).

Table 4 shows HIV risk factors among participants not living with HIV. Respondents' basic knowledge of HIV and acquired immune deficiency syndrome (AIDS) was assessed by asking whether they "knew that AIDS was caused by a virus called HIV." Whereas 97.1\% (509/524) of gay or bisexual men responded they "knew this before today," around 1 in 10 women $(55 / 506,10.9 \%)$ and $14.5 \%(53 / 366)$ of heterosexual men did not. A large proportion $(233 / 500,46.6 \%)$ of gay or bisexual men reported more than 100 lifetime sexual partners, and a similar proportion $(220 / 520,42.3 \%)$ reported more than 11 partners in the past year. In comparison, $2.7 \%$ (13/483) of women and $5.0 \%$ (17/338) of heterosexual men reported 100 or more sexual partners in their lifetime and the majority reported 1 or no sexual partners in the past year. A small proportion of women $(20 / 467,4.3 \%)$ reported no condom use in their last sexual act with a nonregular partner, and $17.2 \%$ (88/511) of gay or bisexual men reported not using a condom in their last sexual encounter with a nonregular partner. 
Table 4. Human immunodeficiency virus (HIV) risk factors among participants not living with diagnosed HIV by gender (men separated by sexual orientation).

\begin{tabular}{|c|c|c|c|}
\hline Risk factors & $\begin{array}{l}\text { Women } \\
\mathrm{n}(\%)\end{array}$ & $\begin{array}{l}\text { Heterosexual men } \\
\mathrm{n}(\%)\end{array}$ & $\begin{array}{l}\text { Gay or bisexual men } \\
\mathrm{n}(\%)\end{array}$ \\
\hline Unaware that $\operatorname{AIDS}^{\mathrm{a}}$ is caused by a virus called $\operatorname{HIV}^{\mathrm{b}}(\mathrm{n}=1396)$ & $55(10.9)$ & $53(14.5)$ & $15(2.9)$ \\
\hline \multicolumn{4}{|l|}{ Total number of lifetime sexual partners ( $n=1321)$} \\
\hline $0-1$ & $100(20.7)$ & $70(20.7)$ & $4(0.8)$ \\
\hline $2-5$ & $188(38.9)$ & $70(20.7)$ & $26(5.2)$ \\
\hline $6-10$ & $70(14.5)$ & $66(19.5)$ & $40(8.0)$ \\
\hline $11-20$ & $64(13.3)$ & $56(16.6)$ & $44(8.8)$ \\
\hline $21-50$ & $37(7.7)$ & $42(12.4)$ & $68(13.6)$ \\
\hline $51-100$ & $11(2.3)$ & $17(5.0)$ & $85(17.0)$ \\
\hline More than 100 & $13(2.7)$ & $17(5.0)$ & $233(46.6)$ \\
\hline \multicolumn{4}{|l|}{ Total number of sexual partners in the past year $(n=1384)$} \\
\hline None & 84 (16.6) & $68(19.0)$ & $20(3.8)$ \\
\hline 1 & $314(61.9)$ & $153(42.9)$ & $43(8.3)$ \\
\hline $2-10$ & $98(19.3)$ & $114(31.9)$ & $237(45.6)$ \\
\hline$\geq 11$ & $11(2.2)$ & $22(6.2)$ & $220(42.3)$ \\
\hline At last sex: no condom use $(n=1308)$ & $337(72.2)$ & $203(61.5)$ & $182(35.6)$ \\
\hline At last sex: no condom and nonregular partner $(n=1308)$ & $20(4.3)$ & $43(13.0)$ & $88(17.2)$ \\
\hline Previously diagnosed with an STI $(\mathrm{n}=952)^{\mathrm{c}, \mathrm{d}}$ & $74(23.9)$ & $44(22.6)$ & $227(50.8)$ \\
\hline Does not know where to access free condoms $(n=1349)$ & $236(48.8)$ & $186(53.6)$ & $242(46.7)$ \\
\hline Cannot afford condoms $(n=661)^{\mathrm{e}}$ & $167(71.7)$ & $112(60.2)$ & $201(83.1)$ \\
\hline \multicolumn{4}{|l|}{ Previously exchanged sex for money, food, or drugs $(n=1346)$} \\
\hline Ever & $36(7.4)$ & $22(6.4)$ & $78(15.1)$ \\
\hline $\mathrm{n}$ the last 12 months $(\mathrm{n}=126)$ & $16(53.3)$ & $11(55.0)$ & $37(48.7)$ \\
\hline \multicolumn{4}{|l|}{ Previously paid for sex $(n=1561)$} \\
\hline Ever & $3(0.6)$ & $122(36.2)$ & $96(18.5)$ \\
\hline In the last 12 months $(\mathrm{n}=209)$ & $0(0)$ & $51(44.3)$ & $35(37.6)$ \\
\hline Experienced forced sex $(n=1331)$ & $55(11.6)$ & $13(3.8)$ & $51(10.0)$ \\
\hline Previously used a needle to inject drugs $(\mathrm{n}=1396)$ & $13(2.6)$ & $12(3.3)$ & $16(3.0)$ \\
\hline Previously shared a needle when injecting drugs $(n=41)$ & $9(69.2)$ & $6(50.0)$ & $5(31.3)$ \\
\hline Used drugs in the last 5 years_-excluding cannabis $(\mathrm{n}=1388)$ & $64(12.8)$ & $54(14.8)$ & $234(44.7)$ \\
\hline Used methamphetamine or $\mathrm{GHB}^{\mathrm{f}}$ or $\mathrm{GBL}^{\mathrm{g}}$ in last 5 years $(\mathrm{n}=1388)$ & $5(1.0)$ & $6(1.6)$ & $66(12.6)$ \\
\hline
\end{tabular}

${ }^{\mathrm{a}}$ AIDS: acquired immune deficiency syndrome.

${ }^{\mathrm{b}} \mathrm{HIV}$ : human immunodeficiency virus.

${ }^{\mathrm{c}}$ STI: sexually transmitted infection.

${ }^{\mathrm{d}}$ Does not include those who have never tested for HIV.

${ }^{\mathrm{e}}$ Only those who cannot access free condoms.

${ }^{\mathrm{f}} \mathrm{GHB}$ : gammahydroxybutyric acid.

${ }^{\mathrm{g}} \mathrm{GBL}$ : gammabutyrolactone.

In the multivariable analysis, the only HIV risk factor significantly associated with previous HIV testing in all groups was the number of lifetime partners (Table 5). For women and heterosexual men, additional associations were found for region of birth. Further factors for women were experience of forced sex (aOR 3.55, 95\% CI 1.40-9.01) and receiving antenatal care postmigration $(3.09,95 \% \mathrm{CI} 1.56-6.13)$. For heterosexual men, additional factors included access to primary care (aOR 2.67, 95\% CI 1.43-4.97), and those with poorer health were less likely to have tested (aOR $0.22,95 \%$ CI $0.22-0.84$ ). 
Table 5. Factors associated with ever having human immunodeficiency virus (HIV) tested among participants not living with diagnosed HIV, by gender (men separated by self-reported sexual orientation).

\begin{tabular}{|c|c|c|c|c|c|}
\hline Factors $^{\mathrm{a}}$ & $\mathrm{n}(\%)$ & $\mathrm{OR}^{\mathrm{b}}$ & $\mathrm{aOR}^{\mathrm{c}}$ & $95 \% \mathrm{CI}$ & $P$ value \\
\hline \multicolumn{6}{|l|}{ Women $(n=426)$} \\
\hline Current region of residence & & & & & .13 \\
\hline Northern Europe & $53(55.2)$ & 0.62 & 0.51 & $0.26-0.99$ & \\
\hline Southern Europe & $147(66.5)$ & 1.00 & 1.00 & - & \\
\hline Western and rest of Europe & $76(69.7)$ & 1.17 & 0.85 & $0.45-1.60$ & \\
\hline Age, years & & & & & .37 \\
\hline $18-24$ & $22(57.9)$ & 0.61 & 0.55 & $0.23-1.30$ & \\
\hline $25-34$ & $119(65.4)$ & 1.00 & 1.00 & - & \\
\hline $35-44$ & $81(70.4)$ & 1.25 & 1.23 & $0.66-2.31$ & \\
\hline $45-54$ & $34(55.7)$ & 0.62 & 0.74 & $0.32-1.67$ & \\
\hline $55+$ & $20(66.7)$ & 1.18 & 1.32 & $0.46-3.85$ & \\
\hline Region of birth & & & & & $<.001$ \\
\hline Africa & $75(84.3)$ & 4.00 & 5.42 & $2.48-11.83$ & \\
\hline Latin America and the Caribbean & $66(68.8)$ & 1.79 & 2.46 & $1.22-4.95$ & \\
\hline Rest of the world & $29(55.8)$ & 0.86 & 0.97 & $0.46-2.05$ & \\
\hline Europe & $106(56.1)$ & 1.00 & 1.00 & - & \\
\hline Years resident in the country & & & & & .06 \\
\hline 1 or less & $34(77.3)$ & 1.31 & 3.09 & $1.13-8.44$ & \\
\hline $2-5$ & $60(55.6)$ & 0.61 & 0.85 & $0.43-1.68$ & \\
\hline $6-9$ & $64(64.6)$ & 0.86 & 1.01 & $0.52-1.95$ & \\
\hline 10 or more & $118(67.4)$ & 1.00 & 1.00 & - & \\
\hline Immigration status & & & & & .13 \\
\hline Permanent residency & $187(66.8)$ & 1.00 & 1.00 & - & \\
\hline Temporary residency & $41(68.3)$ & 0.96 & 0.59 & $0.26-1.33$ & \\
\hline Refugee status, unknown, or undocumented & $48(55.8)$ & 0.71 & 0.44 & $0.20-0.95$ & \\
\hline Total number of lifetime sexual partners & & & & & $<.001$ \\
\hline $0-1$ & $37(47.4)$ & 0.52 & 0.53 & $0.28-1.01$ & \\
\hline $2-5$ & $103(59.5)$ & 1.00 & 1.00 & - & \\
\hline $6-10$ & $42(66.7)$ & 1.28 & 1.54 & $0.76-3.11$ & \\
\hline More than 10 & $94(83.9)$ & 3.43 & 4.25 & $2.16-8.36$ & \\
\hline Experience of forced sex & & & & & .008 \\
\hline No & $235(62.2)$ & 1.00 & 1.00 & - & \\
\hline Yes & $41(85.4)$ & 3.79 & 3.55 & $1.40-9.01$ & \\
\hline Children or antenatal care in CCOR $^{d}$ & & & & & .001 \\
\hline No children & $127(61.7)$ & 1.00 & 1.00 & - & \\
\hline Has children, no antenatal care in CCOR & $69(58.0)$ & 0.82 & 0.77 & $0.41-1.41$ & \\
\hline Has children, antenatal care in CCOR & $80(79.2)$ & 2.36 & 3.09 & $1.56-6.13$ & \\
\hline Self-reported health status & & & & & .07 \\
\hline Very good & $86(78.2)$ & 2.31 & 2.08 & $1.12-3.88$ & \\
\hline Good & $100(57.1)$ & 1.00 & 1.00 & - & \\
\hline Other response & $90(63.8)$ & 1.30 & 1.39 & $0.78-2.46$ & \\
\hline
\end{tabular}




\begin{tabular}{|c|c|c|c|c|c|}
\hline Factors ${ }^{\mathrm{a}}$ & $\mathrm{n}(\%)$ & $\mathrm{OR}^{\mathrm{b}}$ & $\mathrm{aOR}^{\mathrm{c}}$ & $95 \% \mathrm{CI}$ & $P$ value \\
\hline \multicolumn{6}{|l|}{ Heterosexual men $(n=301)$} \\
\hline Current region of residence & & & & & .08 \\
\hline Northern Europe & $20(52.6)$ & 1.06 & 0.93 & $0.38-2.26$ & \\
\hline Southern Europe & $102(51.8)$ & 1.00 & 1.00 & - & \\
\hline Western and rest of Europe & $46(69.7)$ & 2.13 & 2.13 & $1.04-4.35$ & \\
\hline Age, years & & & & & .14 \\
\hline $18-24$ & $22(61.1)$ & 1.46 & 1.79 & $0.74-4.36$ & \\
\hline $25-34$ & $53(51.5)$ & 1.00 & 1.00 & - & \\
\hline $35-44$ & $52(66.7)$ & 1.65 & 1.86 & $0.90-3.81$ & \\
\hline $45-54$ & $26(50.0)$ & 0.78 & 0.93 & $0.40-2.18$ & \\
\hline $55+$ & $15(46.9)$ & 0.71 & 0.57 & $0.20-1.65$ & \\
\hline Region of birth & & & & & .01 \\
\hline Africa & $79(66.4)$ & 1.00 & 1.00 & - & \\
\hline Latin and the Caribbean & $22(59.5)$ & 0.54 & 0.38 & $0.16-0.93$ & \\
\hline Rest of the world & $29(47.5)$ & 0.36 & 0.57 & $0.27-1.18$ & \\
\hline Europe & $38(45.2)$ & 0.32 & 0.32 & $0.16-0.67$ & \\
\hline Years resident in the country & & & & & .71 \\
\hline 1 or less & $20(55.6)$ & 0.85 & 1.45 & $0.54-3.95$ & \\
\hline $2-5$ & $51(55.4)$ & 1.02 & 1.19 & $0.57-2.47$ & \\
\hline $6-9$ & $26(55.3)$ & 1.08 & 0.80 & $0.35-1.85$ & \\
\hline 10 or more & $71(56.3)$ & 1.00 & 1.00 & - & \\
\hline Immigration status & & & & & .57 \\
\hline Permanent residency & $81(55.9)$ & 1.00 & 1.00 & - & \\
\hline Temporary residency & $42(64.6)$ & 1.40 & 1.46 & $0.65-3.27$ & \\
\hline Refugee status, unknown, or undocumented & $45(49.5)$ & 0.77 & 1.03 & $0.45-2.35$ & \\
\hline Total number of lifetime sexual partners & & & & & $<.001$ \\
\hline $0-1$ & $23(35.9)$ & 0.29 & 0.20 & $0.09-0.44$ & \\
\hline $2-5$ & $29(47.5)$ & 0.47 & 0.39 & $0.19-0.80$ & \\
\hline $6-10$ & $35(64.8)$ & 0.93 & 1.00 & $0.46-2.15$ & \\
\hline More than 10 & $81(66.4)$ & 1.00 & 1.00 & - & \\
\hline Access to primary care & & & & & $<.001$ \\
\hline No & $61(47.3)$ & 1.00 & 1.00 & $0.20-0.70$ & \\
\hline Yes & $107(62.2)$ & 1.82 & 2.67 & $1.43-4.97$ & \\
\hline Self-reported health status & & & & & .04 \\
\hline Very good & $49(55.1)$ & 0.65 & 0.68 & $0.36-1.30$ & \\
\hline Good & $81(65.3)$ & 1.00 & 1.00 & - & \\
\hline Other response & $38(43.2)$ & 0.40 & 0.43 & $0.22-0.84$ & \\
\hline \multicolumn{6}{|l|}{ Gay or bisexual men $(n=492)$} \\
\hline Current region of residence & & & & & .64 \\
\hline Northern Europe & $76(87.4)$ & 0.97 & 1.18 & $0.53-2.61$ & \\
\hline Southern Europe & $69(83.1)$ & 0.70 & 0.72 & $0.32-1.66$ & \\
\hline Western and rest of Europe & $282(87.6)$ & 1.00 & 1.00 & - & \\
\hline
\end{tabular}




\begin{tabular}{|c|c|c|c|c|c|}
\hline Factors $^{\mathrm{a}}$ & $\mathrm{n}(\%)$ & $\mathrm{OR}^{\mathrm{b}}$ & $\mathrm{aOR}^{\mathrm{c}}$ & $95 \% \mathrm{CI}$ & $P$ value \\
\hline Age, years & & & & & .35 \\
\hline $18-24$ & $61(72.6)$ & 0.34 & 0.53 & $0.26-1.09$ & \\
\hline $25-34$ & $188(89.1)$ & 1.00 & 1.00 & - & \\
\hline $35-44$ & $115(89.1)$ & 1.10 & 0.75 & $0.32-1.73$ & \\
\hline $45-54$ & $48(96.0)$ & 3.27 & 1.86 & $0.36-9.62$ & \\
\hline $55+$ & $15(83.3)$ & 0.54 & 0.56 & $0.11-2.82$ & \\
\hline Region of birth & & & & & .87 \\
\hline Africa & $22(81.5)$ & 0.71 & 1.18 & $0.31-4.48$ & \\
\hline Latin America and the Caribbean & $119(88.1)$ & 1.21 & 1.34 & $0.62-2.87$ & \\
\hline Rest of the world & $69(87.3)$ & 1.11 & 1.37 & $0.53-3.52$ & \\
\hline Europe & $217(86.5)$ & 1.00 & 1.00 & - & \\
\hline Years resident in the country & & & & & .46 \\
\hline 1 or less & $70(76.9)$ & 0.50 & 0.57 & $0.27-1.23$ & \\
\hline $2-5$ & $153(87.9)$ & 1.00 & 1.00 & - & \\
\hline $6-9$ & $77(90.6)$ & 1.41 & 1.10 & $0.41-2.93$ & \\
\hline 10 or more & $127(89.4)$ & 1.17 & 0.81 & $0.34-1.94$ & \\
\hline Immigration status & & & & & .86 \\
\hline Permanent residency & $321(87.5)$ & 1.00 & 1.00 & - & \\
\hline Temporary residency & $89(87.3)$ & 0.94 & 0.99 & $0.44-2.21$ & \\
\hline Refugee status, unknown, or undocumented & $17(73.9)$ & 0.43 & 0.71 & $0.20-2.54$ & \\
\hline Total number of lifetime sexual partners & & & & & $<.001$ \\
\hline $0-10$ & $56(62.9)$ & 0.06 & 0.07 & $0.02-0.23$ & \\
\hline $11-20$ & $36(78.3)$ & 0.13 & 0.15 & $0.04-0.54$ & \\
\hline $21-50$ & $79(92.9)$ & 0.47 & 0.53 & $0.14-2.01$ & \\
\hline $51-100$ & 73 (91.3) & 0.37 & 0.36 & $0.10-1.33$ & \\
\hline $101-500$ & $112(96.6)$ & 1.00 & 1.00 & - & \\
\hline 501 or more & $71(93.4)$ & 0.51 & 0.49 & $0.12-1.93$ & \\
\hline
\end{tabular}

${ }^{a}$ After model selection, each gender-related group adjusted for the factors listed under the corresponding heading in the table.

${ }^{\mathrm{b}} \mathrm{OR}$ : odds ratio.

$\mathrm{c}_{\mathrm{aOR}}$ : adjusted odds ratio.

${ }^{\mathrm{d}} \mathrm{CCOR}$ : current country of residence.

\section{Discussion}

\section{Principal Findings}

This paper presents findings on access to primary care and HIV testing from the first European study focused on multiple migrant populations. It captures a diverse sample of migrant communities at risk of HIV infection, including migrant gay or bisexual men who form a substantial, relatively underresearched, proportion of the HIV epidemic in Europe. We have shown that determinants of access to primary care are dependent on immigration status and where an individual resides within Europe. A high proportion of participants had previously tested for HIV, but there is evidence that missed opportunities for increasing the uptake of HIV testing remain. A previous history of testing for HIV was strongly associated with sexual behavior.
Accordingly, low perception of risk was identified as one of the main barriers to HIV testing among all 3 gender-related groups.

Previous studies have suggested that cultural factors act as barriers to health-seeking behavior among black African heterosexuals [10,11,17,23,24]. Whereas we found that region of origin influences access to primary care for women and heterosexual men, perhaps providing additional evidence, this association was not present for gay or bisexual men and suggests that other factors influence health-seeking behaviors in this population. Additionally, previous studies have suggested that African migrants have high rates of late diagnosis because this population has different health-seeking norms or competing priorities in comparison with Europeans [7,24]. However, this study found no significant difference in access to primary care 
between migrants from Africa and other regions, with the exception of Latin America and the Caribbean. This suggests that rather than sociodemographic characteristics, cultural practices, or individual health status, it is perhaps the structural factors that present the largest barriers to primary care for migrants, regardless of country of origin.

The importance of such structural or macro-level barriers may indicate changing policies and practices regarding rights to health care of both documented and undocumented migrants (including those whose visas have expired or asylum applications have been rejected). For example, in Spain, the government rescinded access to primary health care for migrants without residency papers in September 2012 only to reinstate it again in March 2015 [25,26]. In the United Kingdom, proposals to charge short-term, temporary, and undocumented migrants for primary medical care were debated in 2013 and partially implemented through a new Immigration Act in 2014 [27]. The impact of these policies regarding health care is perhaps reflected in the findings of our study. However, additional evidence is needed regarding the impact of immigration policies on access to HIV testing for migrants.

Findings are consistent with other studies showing that low perception of risk is a barrier to HIV testing for various migrant or black and minority ethnic communities [11,24,28-30]. Many of those studies focus on the needs of heterosexual migrant men and women. Our study also highlights risk perception as a barrier to testing for migrant gay or bisexual men, which may reflect a difference with nonmigrant gay men. Indeed, the European Men-Who-Have-Sex-With-Men Internet Survey Network found that HIV testing in the last 12 months was negatively associated with migrant status [31]. Given that gay or bisexual men reported fears surrounding the consequences of a positive test result and experienced structural barriers to testing (eg, having to pay for the test, not knowing where to go for a test, and being unable to test anonymously), these findings provide evidence for HIV testing initiatives aimed at migrant gay or bisexual men. Additionally, women and heterosexual men born in Africa were more likely to test than those born in other regions, but given that late presentation remains a feature for these communities [2], structural barriers may be preventing early diagnosis.

There was evidence of missed opportunities for HIV testing. Studies have shown that offering HIV tests in general practice is feasible and acceptable $[17,18]$. Data from this study show that general practice might be a key gateway to improving the uptake and awareness of HIV among migrant populations, particularly among heterosexual men. Given that over $80 \%$ of the participants had visited a doctor or nurse in their current country of residence in the last year and 9 out of 10 had visited some type of health service since migrating, the proportion who recalled HIV being mentioned while at a health service (47\%) is comparatively low. This disparity is particularly problematic in services where there should be a policy of a routine offer or opt-out for HIV testing. Less than half of women recalled anyone mentioning HIV in antenatal care. Given that opt-out or universal HIV testing at antenatal services is available in almost all the countries featured in this survey [32], it is possible that the women tested but did not recall being offered the test. As routine testing is also available at sexual health clinics in these countries [33], the same explanation could account for our finding that nearly half of women and heterosexual men were not offered an HIV test at that service.

In addition to the structural barriers to accessing health care and HIV testing, this study provides evidence of individual-level obstacles to HIV prevention and testing. Over 1 in 10 women and heterosexual men did not have basic HIV knowledge; in all groups, around half of the respondents did not know where to access free condoms and $17 \%$ to $40 \%$ of those who did not know where to access condoms could not afford them. Whereas the finding about basic HIV knowledge might be consistent with other studies [34], we nevertheless highlight the importance of continued HIV knowledge and awareness initiatives aimed at migrant communities.

\section{Limitations}

Our study has a number of limitations [20]. Our sample is a convenience sample; therefore, it is not representative of the European migrant population. Over half of those who consented to the survey did not complete it. Given that attrition was largely confined to the first part of the survey (the curiosity plateau), it is possible that those who dropped out at that stage had consented out of curiosity and withdrew when the survey did not meet their expectations [35]. The very large percentage of men who have sex with men in the survey reflects our targeting and advertising strategy. Individuals who fall into more than 1 population group (eg, Latin American men who have sex with men) may have been exposed to advertising and marketing on multiple occasions and different media. Nevertheless, by conducting analyses separately within gender-related subgroups, we have limited bias in our findings.

In this sample, the proportion of respondents who reported living with HIV was similar to another study that used community mobilization and engagement recruitment methods [36]. It is also possible that the high proportion of respondents who had visited an HIV doctor in the past 12 months also reflects the recruitment strategy used in this survey, particularly as around half of the respondents living with HIV reported contact with a nongovernmental organization providing HIV support (data not shown). Regardless of the recruitment methods, our findings show people living with HIV are missing appointments and forgoing or delaying medication for financial reasons. This suggests that there are possible implications for treatment adherence and service attendance.

\section{Conclusion}

Improving access to primary care and HIV testing represents an important strategy to reduce the risk of postmigration acquisition of HIV and reduce ill health among migrants in Europe. Our data suggest that improving access to GPs, particularly for migrants without permanent residency permits, could increase the uptake of HIV testing. Clinicians and others should consider the impact of structural policies that inhibit access to HIV testing as well as interventions that increase individual knowledge, raise awareness of risk, or induce behavior change. 


\section{Acknowledgments}

This project received funding from the European Union's Seventh Framework Programme for research, technological development, and demonstration under EuroCoord grant agreement number 260694. IF was funded by a Doctoral Research Fellowship from the National Institute for Health Research (NIHR). The views expressed in this paper are those of the authors and not necessarily those of the National Health Service (NHS), the National Institute for Health Research (NIHR), or the Department of Health. Additional funding was received from Gilead Sciences Europe Ltd; NIHR Clinical Research Network, the United Kingdom; Foundation for AIDS Research and Prevention in Spain (FISPSE) Project 361036/10; Consortium of Biomedical Research in Epidemiology and Public Health, Spain; Spanish HIV Research Network for Excellence (RD06/006 and RD12/0017/0018); Research and Development Fund, Public Health Service of Amsterdam; and the Swiss HIV Cohort Study (project \#727), supported by the Swiss National Science Foundation (grant \#148522) and by the Swiss HIV Cohort Study research foundation. No funder had any role in the study, writing of the manuscript, or decision to submit for publication.

This study would not have been possible without the entire Work Package 14 collaboration. We would especially like to thank our Community Advisory Group: Bryan Teixeira, Bisi Alimi, Janneke Bil, Koen Block, Anna Coluzzi, Marc Dixneuf, Andy Gregg, Jason Farrell, Anna-Maria Luzzi, Maureen Louhenapessy, Alberto Martin-Perez, Tatiana Mouhebati, Godwyns Onwuchekwa, Jenifer Rebollo, Ramazan Salman, Diana Silva, Miguel Vazquez, Alain Volny-Anne, Nicky Voudouri, Wim Zuilhof, and Freke Zuure.

\section{Conflicts of Interest}

None declared.

\section{Multimedia Appendix 1}

Sociodemographic characteristics of respondents.

[XLSX File (Microsoft Excel File), 18KB-Multimedia Appendix 1]

\section{Multimedia Appendix 2}

Current country of residence of all participants in the Advancing Migrant Access to Health Services in Europe Community Survey. Color gradient indicates number of participants, with color increasing in saturation with increasing number of people. $\mathrm{N}=1637$.

[JPG File, 249KB-Multimedia Appendix 2]

\section{Multimedia Appendix 3}

Country of birth of all eligible participants in the Advancing Migrant Access to Health Services in Europe Community Survey. Color gradient indicates number of participants, with color increasing in saturation with increasing number of people. $\mathrm{N}=1637$.

[JPG File, 325KB-Multimedia Appendix 3]

\section{References}

1. Hernando V, Alvárez-del Arco D, Alejos B, Monge S, Amato-Gauci AJ, Noori T, et al. HIV infection in migrant populations in the European Union and European economic area in 2007-2012: an epidemic on the move. J Acquir Immune Defic Syndr 2015 Oct 01;70(2):204-211. [doi: 10.1097/QAI.0000000000000717] [Medline: 26068723]

2. European Centre for Disease Prevention and Control, WHO Regional Office for Europe. HIV/AIDS surveillance in Europe 2015. Stockholm: European Centre for Disease Prevention and Control; 2016.

3. Fakoya I, Álvarez-del Arco D, Woode-Owusu M, Monge S, Rivero-Montesdeoca Y, Delpech V, et al. A systematic review of post-migration acquisition of HIV among migrants from countries with generalised HIV epidemics living in Europe: implications for effectively managing HIV prevention programmes and policy. BMC Public Health 2015 Jun 19;15:561 [FREE Full text] [doi: 10.1186/s12889-015-1852-9] [Medline: 26085030]

4. Weine SM, Kashuba AB. Labor migration and HIV risk: a systematic review of the literature. AIDS Behav 2012 Aug;16(6):1605-1621 [FREE Full text] [doi: 10.1007/s10461-012-0183-4] [Medline: 22481273]

5. Haour-Knipe M. Migration and HIV/AIDS in Europe. In: AIDS Infotheque. Switzerland: Sida Info Doc Suisse; Oct 2000:4-14.

6. Rechel B, Mladovsky P, Ingleby D, Mackenbach JP, McKee M. Migration and health in an increasingly diverse Europe. Lancet 2013 Apr 06;381(9873):1235-1245. [doi: 10.1016/S0140-6736(12)62086-8] [Medline: 23541058]

7. Prost A, Elford J, Imrie J, Petticrew M, Hart GJ. Social, behavioural, and intervention research among people of Sub-Saharan African origin living with HIV in the UK and Europe: literature review and recommendations for intervention. AIDS Behav 2008 Mar;12(2):170-194. [doi: 10.1007/s10461-007-9237-4] [Medline: 17497218] 
8. Burns FM, Johnson AM, Nazroo J, Ainsworth J, Anderson J, Fakoya A, SONHIA Collaboration Group. Missed opportunities for earlier HIV diagnosis within primary and secondary healthcare settings in the UK. AIDS 2008 Jan 02;22(1):115-122. [doi: 10.1097/QAD.0b013e3282f1d4b6] [Medline: 18090399]

9. Fakoya I, Reynolds R, Caswell G, Shiripinda I. Barriers to HIV testing for migrant black Africans in Western Europe. HIV Med 2008 Jul;9(Suppl 2):23-25 [FREE Full text] [doi: 10.1111/j.1468-1293.2008.00587.x] [Medline: 18557866]

10. Manirankunda L, Loos J, Debackaere P, Nöstlinger C. "It is not easy": challenges for provider-initiated HIV testing and counseling in Flanders, Belgium. AIDS Educ Prev 2012 Oct;24(5):456-468. [doi: 10.1521/aeap.2012.24.5.456] [Medline: 23016506]

11. Manirankunda L, Loos J, Alou TA, Colebunders R, Nöstlinger C. "It's better not to know": perceived barriers to HIV voluntary counseling and testing among sub-Saharan African migrants in Belgium. AIDS Educ Prev 2009 Dec;21(6):582-593. [doi: 10.1521/aeap.2009.21.6.582] [Medline: 20030501]

12. Evans AR, Parutis V, Hart G, Mercer CH, Gerry C, Mole R, et al. The sexual attitudes and lifestyles of London's Eastern Europeans (SALLEE Project): design and methods. BMC Public Health 2009 Oct 30;9:399 [FREE Full text] [doi: 10.1186/1471-2458-9-399] [Medline: 19878564]

13. Weine S, Bahromov M, Loue S, Owens L. Trauma exposure, PTSD, and HIV sexual risk behaviors among labor migrants from Tajikistan. AIDS Behav 2012 Aug;16(6):1659-1669 [FREE Full text] [doi: 10.1007/s10461-011-0122-9] [Medline: 22261829]

14. Wirtz AL, Zelaya CE, Peryshkina A, Latkin C, Mogilnyi V, Galai N, et al. Social and structural risks for HIV among migrant and immigrant men who have sex with men in Moscow, Russia: implications for prevention. AIDS Care 2014;26(3):387-395 [FREE Full text] [doi: 10.1080/09540121.2013.819407] [Medline: 23875610 ]

15. Angel C, Paz Bermúdez M. Native and immigrant adolescents in Spain: adaptation and perceived discrimination as HIV-risk factors. Int J Clin Health Psychol 2011 Jan;11:35-47 [FREE Full text]

16. Esteban-Vasallo MD, Morán-Arribas M, García-Riolobos C, Domínguez-Berjón MF, Rico-Bermejo J, Collado-González $\mathrm{S}$, et al. Targeted rapid HIV testing in public primary care services in Madrid. Are we reaching the vulnerable populations? Int J Infect Dis 2014 Feb;19:39-45 [FREE Full text] [doi: 10.1016/j.ijid.2013.10.006] [Medline: 24269650]

17. Loos J, Manirankunda L, Hendrickx K, Remmen R, Nöstlinger C. HIV testing in primary care: feasibility and acceptability of provider initiated HIV testing and counseling for sub-Saharan African migrants. AIDS Educ Prev 2014 Feb;26(1):81-93. [doi: 10.1521/aeap.2014.26.1.81] [Medline: 24450280]

18. Prost A, Griffiths CJ, Anderson J, Wight D, Hart GJ. Feasibility and acceptability of offering rapid HIV tests to patients registering with primary care in London (UK): a pilot study. Sex Transm Infect 2009 Sep;85(5):326-329. [doi: 10.1136/sti.2008.033233] [Medline: 19487214]

19. Lewis NM, Wilson K. HIV risk behaviours among immigrant and ethnic minority gay and bisexual men in North America and Europe: a systematic review. Soc Sci Med 2017 Apr;179:115-128. [doi: 10.1016/j.socscimed.2017.02.033] [Medline: 28260636]

20. Fakoya I, Álvarez-Del Arco D, Monge S, Copas AJ, Gennotte AF, Volny-Anne A, et al. Advancing migrant access to health services in Europe (AMASE): protocol for a cross-sectional study. JMIR Res Protoc 2016 May 16;5(2):e74 [FREE Full text] [doi: 10.2196/resprot.5085] [Medline: 27185491]

21. del Amo J, Pérez-Cachafeiro S, Hernando V, González C, Jarrín I, Bolúmar F. Migrant health: epidemiology of HIV and AIDS in migrant communities and ethnic minorities in EU/EEA countries. 2010. URL: https://ecdc.europa.eu/sites/portal/ files/media/en/publications/Publications/0907_TER_Migrant_health_HIV_Epidemiology_review.pdf [accessed 2017-08-30] [WebCite Cache ID 6t6ovA6vm]

22. United Nations Statistics Division: Methodology. 2017. URL: https://unstats.un.org/unsd/methodology/m49/ [accessed 2017-06-14] [WebCite Cache ID 6rDcL2d4M]

23. Burns F, Fenton KA. Access to HIV care among migrant Africans in Britain. What are the issues? Psychol Health Med 2006 Feb;11(1):117-125. [doi: 10.1080/13548500500156527] [Medline: 17129901]

24. Burns FM, Imrie JY, Nazroo J, Johnson AM, Fenton KA. Why the(y) wait? Key informant understandings of factors contributing to late presentation and poor utilization of HIV health and social care services by African migrants in Britain. AIDS Care 2007 Jan;19(1):102-108. [doi: 10.1080/09540120600908440] [Medline: 17129864]

25. Illegal immigrants to regain free healthcare.: The Local; 2015 Mar 31. URL: https://www.thelocal.es/20150331/ spain-to-restore-free-health-care-for-illegal-immigrants [accessed 2017-08-30] [WebCite Cache ID 6t6pRyfdI]

26. Tremlett G. Immigrants in Spain to lose right to public healthcare.: The Guardian; 2012 Aug 31. URL: https://www. theguardian.com/world/2012/aug/31/immigrants-spain-lose-public-healthcare [accessed 2017-05-17] [WebCite Cache ID $\underline{6 \mathrm{qW} v \mathrm{vheDq}]}$

27. Gower M. Immigration Health Surcharge: common casework questions.: Research Briefings UK Parliament; 2015 Aug 06. URL: http://researchbriefings.parliament.uk/ResearchBriefing/Summary/CBP-7274 [accessed 2017-05-17] [WebCite Cache ID 6qWvmCIJW]

28. Burns F, Fenton KA, Morison L, Mercer C, Erens B, Field J, et al. Factors associated with HIV testing among black Africans in Britain. Sex Transm Infect 2005 Dec;81(6):494-500 [FREE Full text] [doi: 10.1136/sti.2004.013755] [Medline: 16326854] 
29. Anderson J. Coming and going: some aspects of care for migrants with HIV in the UK. J Infect 2008 Jul;57(1):11-15. [doi: 10.1016/j.jinf.2008.05.002] [Medline: 18541306]

30. Anderson M, Elam G, Gerver S, Solarin I, Fenton K, Easterbrook P. "It took a piece of me": initial responses to a positive HIV diagnosis by Caribbean people in the UK. AIDS Care 2010 Dec;22(12):1493-1498. [doi: 10.1080/09540121.2010.482125] [Medline: 20824553]

31. EMIS 2010: The European Men-Who-Have-Sex-With-Men Internet Survey. Findings from 38 countries. Stockholm: European Centre for Disease Prevention and Control; 2013. URL: https://ecdc.europa.eu/sites/portal/files/media/en/ publications/Publications/EMIS-2010-european-men-who-have-sex-with-men-survey.pdf [accessed 2017-09-06] [WebCite Cache ID 6tGx01Jhv]

32. Savolainen-Kopra C, Kontio M, Lindeman J, Isojärvi J, Liitsola K, Mäkelä M, ECDC. Antenatal screening for HIV, hepatitis $\mathrm{B}$, syphilis and rubella susceptibility in the EU/EEA—addressing the vulnerable populations. Stockholm: ECDC; 2016 Mar 30. URL: https://ecdc.europa.eu/sites/portal/files/media/en/publications/Publications/antenatal-screening-sci-advice-2017. pdf [accessed 2017-09-06] [WebCite Cache ID 6tGxBSGdP]

33. Mounier-Jack S, Nielsen S, Coker RJ. HIV testing strategies across European countries. HIV Med 2008 Jul;9(Suppl 2):13-19 [FREE Full text] [doi: 10.1111/j.1468-1293.2008.00585.x] [Medline: 18557864]

34. Hickson F, Owuor J, Weatherburn P, Reid D, Hammond G, Jessup K. Bass Line 2008-09: assessing the sexual HIV prevention needs of African people in England. Project Report. London: Sigma Research; 2009. URL: http://sigmaresearch. org.uk/files/report2009h.pdf [accessed 2017-08-30] [WebCite Cache ID 6t6qvDHls]

35. Eysenbach G. The law of attrition. J Med Internet Res 2005 Mar 31;7(1):e11 [FREE Full text] [doi: 10.2196/jmir.7.1.e11] [Medline: 15829473 ]

36. Sadler KE, McGarrigle CA, Elam G, Ssanyu-Sseruma W, Davidson O, Nichols T, et al. Sexual behaviour and HIV infection in black-Africans in England: results from the Mayisha II survey of sexual attitudes and lifestyles. Sex Transm Infect 2007 Dec;83(7):523-529 [FREE Full text] [doi: 10.1136/sti.2007.027128] [Medline: 17932129]

\author{
Abbreviations \\ AIDS: acquired immune deficiency syndrome \\ aMASE: Advancing Migrant Access to Health Services in Europe \\ aOR: adjusted odds ratio \\ CAG: Community Advisory Group \\ CCOR: current country of residence \\ COB: country of birth \\ FISPSE: Foundation for AIDS Research and Prevention in Spain (Spanish) \\ GBL: gammabutyrolactone \\ GHB: gammahydroxybutyric acid \\ GP: general practitioner \\ HIV: human immunodeficiency virus \\ IQR: interquartile range \\ NIHR: National Institute for Health Research \\ NHS: National Health Service \\ OR: odds ratios \\ STI: sexually transmitted infection \\ WHO: World Health Organization
}

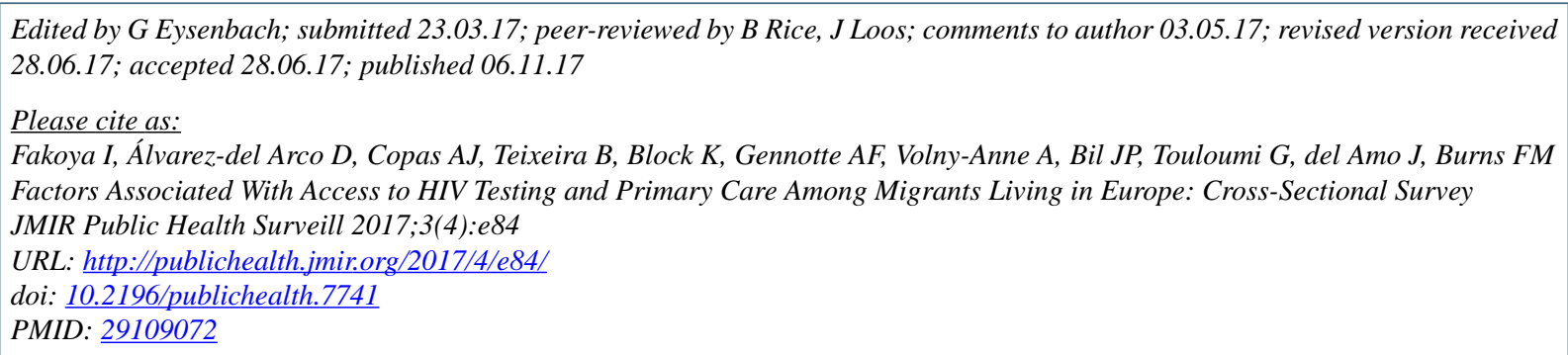

CIbidun Fakoya, Débora Álvarez-del Arco, Andrew J Copas, Bryan Teixeira, Koen Block, Anne-Francoise Gennotte, Alain Volny-Anne, Janneke P Bil, Giota Touloumi, Julia del Amo, Fiona M Burns. Originally published in JMIR Public Health and 
Surveillance (http://publichealth.jmir.org), 06.11.2017. This is an open-access article distributed under the terms of the Creative Commons Attribution License (https://creativecommons.org/licenses/by/4.0/), which permits unrestricted use, distribution, and reproduction in any medium, provided the original work, first published in JMIR Public Health and Surveillance, is properly cited. The complete bibliographic information, a link to the original publication on http://publichealth.jmir.org, as well as this copyright and license information must be included. 